\title{
Talviaikaisen jaloittelun vaikutus lypsylehmän hyvinvointiin
}

\author{
Hanna-Kaisa Ruuskanen ${ }^{1,2)}$, Arja Korhonen ${ }^{1)}$, Hilkka Kämäräinen ${ }^{1)}$, Heli Wahlroos ${ }^{1)}$ \\ 1)Savonia-ammattikorkeakoulu,PL 72, 74101 Iisalmi, etunimi.sukunimi@savonia.fi \\ 2) hanna-kaisa.ruuskanen@helsinki.fi
}

Talviaikaisella jaloittelulla voidaan tukea lypsylehmien hyvinvointia, erityisesti parsinavetoissa. Talviaikaisen jaloittelun avulla voidaan kohentaa myös yrittäjien ja tilan työntekijöiden hyvinvointia. Navettarakennus olisi esimerkiksi helpompi siivota, kun eläimet ovat ulkona. Talviaikainen jaloittelu on talla hetkellä pakollista vain luomutuotantoon sitoutuneissa parsinavetoissa kaksi kertaa viikossa talvikauden aikana. Talviaikaisella jaloittelulla on havaittu olevan positiivinen vaikutus eläinten hyvinvointiin. Tämän tutkimuksen tavoitteena oli selvittää talviaikaisen jaloittelun vaikutuksia lypsylehmien hyvinvointiin sekä lisätä tietoa talviaikaisesta jaloittelusta. Tutkimus tehtiin maitotiloille suunnattuna valtakunnallisena kyselytutkimuksena. Vastauksia analysoitiin ja vertailtiin kirjallisuudesta muodostettuun käsitykseen jaloittelun vaikutuksista. Navettatyypit jakaantuivat seuraavasti: parsinavetoita $47 \%$ ja pihattonavetoita $52 \%(n=219)$. Tavanomaista tuotantoa harjoittavista $(n=210)$ maitotiloista 20\% ulkoilutti eläimiään talvella. Jaloittelualueena jaloittelevista tiloista puolella oli käytössä erikseen rakennettu jaloittelutarha. Eläimet ulkoilivat kerralla yleisimmin vapaasti (31\%) tai 1-2 tuntia (33\%). Talviaikaisen jaloittelun todettiin edistävän etenkin parsinavetoiden eläinten hyvinvointia. Parsinavetan eläinten koettiin voivan paremmin ja olevan virkeämpiä. Eläinten lihaskunto koheni selkeästi jaloittelun avulla ja kohentunut lihaskunto näkyi erityisesti varmempana ylösnousemisena heti poikimisen jälkeen. Pihattonavetoissa talviaikaisella jaloittelulla ei saavutettu yhtä näkyvia vaikutuksia, koska eläimet voivat liikkua navetassa koko ajan vapaasti. Sorkkaterveyden mainittiin parantuneen pihatoissakin lumessa jaloittelun myötä. Eläinten sanottiin olevan virkeämpiä ja nauttivan jaloittelutarhassa oleskelusta. Kyselyyn vastanneista suurin osa käytti jaloittelutarhana rakennettua tarhaa tai kesäaikaista laidunta. Talviaikaisesta jaloittelusta oli luopumassa tai luopunut 4\% vastaajista (n=219). Pääasiallisin syy luopumiseen oli lisääntynyt loukkaantumisriski (liukkaus) sekä ulkoilutuksen vaatima ajan käyttö. Kyselyyn vastanneista tavanomaista tuotantoa harjoittavista maitotiloista (n=210) 76\% ei ulkoiluttanut eläimiä lainkaan talviaikaan. Talviaikainen jaloittelu koettiin hankalasti toteutettavaksi. Usealla tilalla jaloittelun esteeksi muodostui navetan huono sijainti eli tarhaa ei voitaisi järkevästi rakentaa karjasuojan yhteyteen. Myös liian suuri karjakoko ja yrittäjien oma asenne talvijaloittelua kohtaan rajoitti talviaikaista jaloittelua.

Asiasanat: talvijaloittelu, jaloittelutarhat, lypsykarja, hyvinvointi 


\section{Johdanto}

Tuotantoeläinten hyvinvoinnin perustana voidaan pitää Farm Animal Welfare Commiteen vuonna 1993 määrittelemää viittä vapautta. Näitä vapauksia täydentää kansallisella tasolla eläinsuojelulaki, joka on laadittu vuonna 1996. Eläinsuojelulakia ollaan tällä hetkellä uudistamassa, koska sitä halutaan nykyaikaistaa. Esimerkiksi eläimen mahdollisuus luontaiseen käyttäytymiseen on tärkeää lakiuudistuksessa (Maa- ja metsätalousministeriö.)

Ympärivuotisella jaloittelulla voidaan vastata juuri siihen haasteeseen, jonka parsinavetat eläinten hyvinvoinnille luovat. Läpi vuoden jatkuva ulkoilu mahdollistaisi eläimille lajitovereiden seuran ja luontaisen liikkumisen tarpeen täyttämisen. Paikallaan navetassa seisova eläin ei voi täyttää luontaisia käyttäytymistarpeitaan, koska navettaympäristö estää eläimen liikkumista. Ulkona navettarakenteet tai navetan päivärytmi eivät rajoita eläimen luontaista käyttäytymistä. Parsinavetoiden kieltämisen sijasta olisi järkevämpää tukea entistä voimakkaammin talviaikaista jaloittelua. Myös jaloittelun vaikutusten tarkempi tutkiminen olisi tärkeää.

Toteutetun tutkimuksen avulla haluttiin koota yhteen aiemmissa tutkimuksissa todennettuja jaloittelun ja liikunnan positiivisia vaikutuksia lypsylehmien hyvinvointiin. Talviaikaisen jaloittelun osalta mietittiin talven tuomia haasteita ja mahdollisia vaaranpaikkoja eläinten hyvinvoinnille. Kyselytutkimuksen päätarkoituksena oli kartoittaa, millaisena yrittäjät kokevat jaloittelun merkityksen eläinten hyvinvoinnin ja terveyden kannalta. Erityisesti heidän näkemyksensä siitä, onko jaloittelu vaikuttanut eläinten hedelmällisyyteen, sorkkaterveyteen ja poikimisten sujumiseen olivat tärkeitä. Jaloittelun yleisyyttä ja jaloittelun olosuhteita halutiin saada selville, koska tilastoitua tietoa aiheesta ei juurikaan ole. Jaloittelutarhaan ja sen pohjamateriaalien soveltuvuutta käyttöön kartoitettiin, jotta niiden soveltuvuutta voitaisiin tarkastella kriittisesti. Tutkimuksen kannalta oli mielenkiintoista selvittää ei-jaloittelevien tilojen asennetta jaloittelua kohtaan. Jaloittelusta luopuvilta tai luopuneilta tiloilta haettiin näkemystä siihen, millaisissa tilanteissa jaloittelu ei enää onnistu tai ole järkevää.

\section{Materiaali ja menetelmät}

Kyselytutkimus toteutettiin kahden tutkimuksen yhteisenä kyselynä, toinen tutkimus keskittyi umpilehmien ruokintaan. Tutkimuksessa luotiin Webropol-ohjelmalla kyselylomake, joka lähetetiin Valion kautta heidän yhteystietorekisterissään oleville maitotiloille tuottajin oman sähköisen palvelunsa eli Valman kautta erillisenä tiedoksiantona. Kysely oli auki 19 päivää, jonka aikana kyselyyn pystyi vastaamaan.

Kyselyn linkkiä jaettiin myös Facebookissa maatalousalan ammattiryhmien kautta. Näin pyrittiin saamaan kyselyyn riittävä vastaajamäärä, jotta saatu tutkimustieto olisi pätevää ja sitä voitaisiin yleistää koskemaan laajempaa joukkoa. Tähän tarkoitukseen valittiin Maatilat kuntoon- ja Maajussit- ryhmä sekä Savonian luonnonvara-alan opiskelijoiden opiskelijayhdistyksen SAIMOn ryhmä. Kyseisissä ryhmissä kyselyyn oli vastausaikaa kymmenen päivää.

\section{Tulokset}

Maitotiloille lähetettyyn kyselyyn tuli vastauksia yhteensä 219 kappaletta. Vastaajatiloista yhdeksän kappaletta eli neljä prosenttia oli luomutuotannossa ja loput 210 tilaa (96\%) tavanomaisessa tuotannossa. Tavanomaisen tuotannon tiloista eli 210 vastaajasta $20 \%$ ulkoilutti eläimiään talvella. Ulkoiluttavista tiloista parsinavetta oli 18 tilalla, 23 tilalla oli pihattonavetta ja yhdellä oli kombinavetta. Selkeästi eniten talvisaikaan jaloiteltiin lypsy- ja umpilehmiä.

Jaloittelualueena jaloittelevista tiloista puolella oli käytössä erikseen rakennettu jaloittelutarha. Laitumella eläimiään jaloitteli $24 \%$ ja miltei kaikissa laiduntarhoissa käytettiin sähkölankaa aitausmateriaalina. Vastaavasti tarhoissa, joiden yhteydessä oli myös laidunta, yleisimmät aitarakenteet olivat sähkö- tai metalliaita. Yllättävää oli, että melko isossa osassa rakennettuja jaloittelutarhoja (19\%) oli pelkkä sähköaita. Rakennetuissa tarhoissa puuaita oli puolella vastaajista. Kaikissa metsälaitumissa käytettiin sähköaitaa. Tarkemman jakauman eri jaloittelutarhojen osalta näkee Kuvasta 1. 


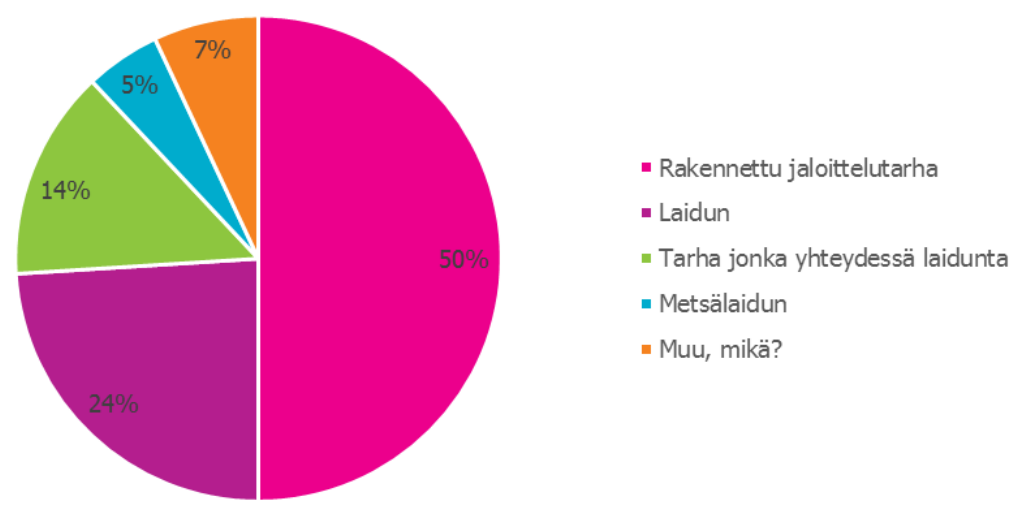

Kuva 1. Nautojen jaloittelutarhojen tyypit $(n=42)$

Eläimet ulkoilevat kerralla yleensä vapaasti (31\% vastaajista) tai parisen tuntia (33\%). Yli kaksi tuntia eläimiään jaloitteli $21 \%$ ja alle tunnin $14 \%$. Koska pihattonavetoissa jaloittelutapa, on vapaa ja eläimet pääsevät oman valintansa mukaan navettaan, ei tarhaan ollut järjestetty juonti- tai syöntimahdollisuutta. Parsinavetoissa, joissa ulkoilutettiin eläimiä, oli yleisempää ruokkia eläimiä ulos. Apuna ruokkimisessa käytettiin usealla tilalla paalihäkkejä.

Vastaajat olivat pääosin hyvin tyytyväisiä jaloittelutarhaansa ja pitivät jaloittelualueitaan tarkoitukseensa hyvin sopivina. Laidunta jaloittelualueena käyttävät olivat hieman vähemmän tyytyväisiä jaloittelualueen pohjamateriaaliin tai puhtaanapitoon, kuin rakennettua jaloittelutarhaa käyttävät.

\section{Jaloittelun vaikutukset eläinten hyvinvointiin}

Talviaikana eläimiään jaloittelevilla tiloilla oltiin hyvin samaa mieltä siitä, että eläimet ovat virkeämpiä ja ne menevät mielellään ulos. Myös sorkkaterveyden koettiin olevan parempi ulkoilutuksen myötä. Vastaavasti kiimakierron selkeytymisestä ja lihaskunnon paranemisesta jaloittelun myötä ollaan hieman eri mieltä. Ilmeisesti tiloilla on ollut jonkin verran tapaturmia, sillä yrittäjät ovat kokeneet, että jaloittelu on jonkin verran lisännyt tapaturmia, sillä väittämän kanssa ollaan hieman eri mieltä. Talviaikaisen jaloittelun vaikutuksista poikimiseen yrittäjillä ei ollut selkeää näkemystä.

Vastaajien mielestä talvijaloittelun haasteista merkittävin on liukkaus. Pari yrittäjää korostaa, että jaloittelu sujuu helpommin ja vaivattomammin, jos eläimet pääsevät säännöllisesti ulos. Pihattonavetoiden omistajat kommentoivat, että he ovat huomanneet talviaikaisen jaloittelun parantaneen erityisesti eläinten sorkkaterveyttä. Jaloittelun vaikutus hedelmällisyyteen ja poikimiseen ei ole niin näkyvä, sillä eläimet liikkuvat pihatossa jo muutoinkin. Pihatoissa jaloittelun järjestämisen lisäämän työajan koetaan kompensoituvan navetan helpompana siistinä pitämisenä.

\section{Talvisaikaan jaloittelemattomat ja jaloittelusta luopumassa olevat tilat}

Tavanomaisen tuotannon tiloista 76\% eli 159 tilaa ei ulkoiluta eläimiään talvisaikaan $(n=210)$. Parsinavetallisten mielestä talviaikaista jaloittelua estää liian hankala toteutettavuus, joka oli syynä jaloittelemattomuuteen $71 \%$ vastaajista. Myös pihattonavetoiden omistajilla yleisin syy jaloittelemattomuuteen oli sama (82\% pihattovastaajista). Seuraavaksi eniten pihatoissa mainintoja saivat liian kalliit investoinnit (65\%), toisena parsinavetoissa oli sen työmäärän lisäävä vaikutus (68\%). Sekä parsi- että pihattonavettavertailussa eniten mainintoja tuli tilanpuutteelle navetan ympärillä tai navetan sijainnille. Eli navetan lähipiiriin ei pystytä järkevästi tekemään jaloittelualuetta, jossa eläimet voisivat jaloitella. Muita yleisiä syitä jaloittelemattomuuteen oli korkea loukkaantumisriski liukkaalla tai sen pelko. Myös työvoiman puute mainittiin usealla vastaajalla, koska varsinkin parsinavetassa yksin eläimiä ei saisi sisälle.

Robottinavetoissa muista syistä tärkeimmäksi nousi se, että jaloittelu ei sopisi robotin kiertoon vaan sotkisi sen. Tämä kuulostaa hieman epätodennäköiselle, koska pihattonavetoissa ja robotin yhteydessä jaloittelu olisi helppo järjestää esimerkiksi älyporttien avulla. Tällöin eläin pääsisi ulos vain, jos sillä 
olisi lupa mennä ulos. Vain seitsemän tilallista kirjoittaa, että talvijaloittelusta ei ole hyötyä tai että kesäaikaisen laidunnuksen tulisi riittää. Viidellä tilalla myönnettiin, että oma laiskuus on syy jaloittelemattomuuteen, vaikka se koettaisiin eläinten kannalta positiivisena asiana. Talviaikaisesta jaloittelusta oli luopumassa tai luopunut neljä prosenttia vastaajista eli yhdeksän tilaa. Pääasialliseksi syyksi talviaikaisesta jaloittelusta luopumiseen ilmoitetaan liukkaus, joka sai maininnan yhteensä viideltä tilalliselta. Kolme yrittäjistä mainitsee syyksi sen, että jaloittelu on paljon aikaa vievää. Kahdella tilalla laajennus on saanut luopumaan jaloittelusta, koska eläinryhmät koetaan nykyisellään liian isoiksi jaloitteluun.

Talviaikaisessa jaloittelussa oli havaittu joitakin hyviä puolia, mutta ne eivät olleet saaneet yrittäjiä jatkamaan jaloittelua. Jaloittelun kerrotaan parantaneen erityisesti sorkkaterveyttä ja puhdistaneen sorkkia. Myös eläinten mielialan nähtiin kohentuneen jaloittelun avulla. Yksi tila mainitsee, että poikimiset eivät venyneet silloin, kun tilan eläimet jaloittelivat. Muutoin terveydessä ei nähty suurempia muutoksia jaloittelun myötä.

\section{Jaloittelevien ja ei jaloittelevien tilojen tulosten vertailu}

Kyselytutkimuksen tulosten perusteella vertailtiin jaloitelleiden ja ei-jaloitelleiden tilojen tuloksia. Vertailun kautta olisi mahdollista löytää aineistosta selkeitä eroja kyseisten ryhmien välillä. Tarkemmin näitä syitä tutkimalla voitaisiin löytää yhteys talviaikaiseen jaloitteluun.

Eläimiään talvisaikaan jaloitelleilla tiloilla yleisimmäksi poiston syyksi ilmoitetaan hedelmällisyysongelmat ja utaresairaudet. Muu, mikä? -vaihtoehtoon vastasi $21 \%$ jaloitelleista tiloista ja eniten mainintoja sai luonne, utarerakenne ja vanhuus. Eläimiään ei ulkoiluttavien yleisimmät poiston syyt ovat samat, mutta utaresairauksien vuoksi poistettiin eniten eläimiä. Hedelmällisyysongelmat tulivat vasta selkeästi toisena. Muu, mikä? -vastausvaihtoehtoon vastasi $22 \%$ ja eniten mainintoja sai lypsettävyys. Mainintoja sai myös poikimisongelmat, poikimahalvaus, vanhuus, luonne ja utarerakenne. Tarkemmat jakaumat eri poiston syihin voi nähdä Kuvasta 2.

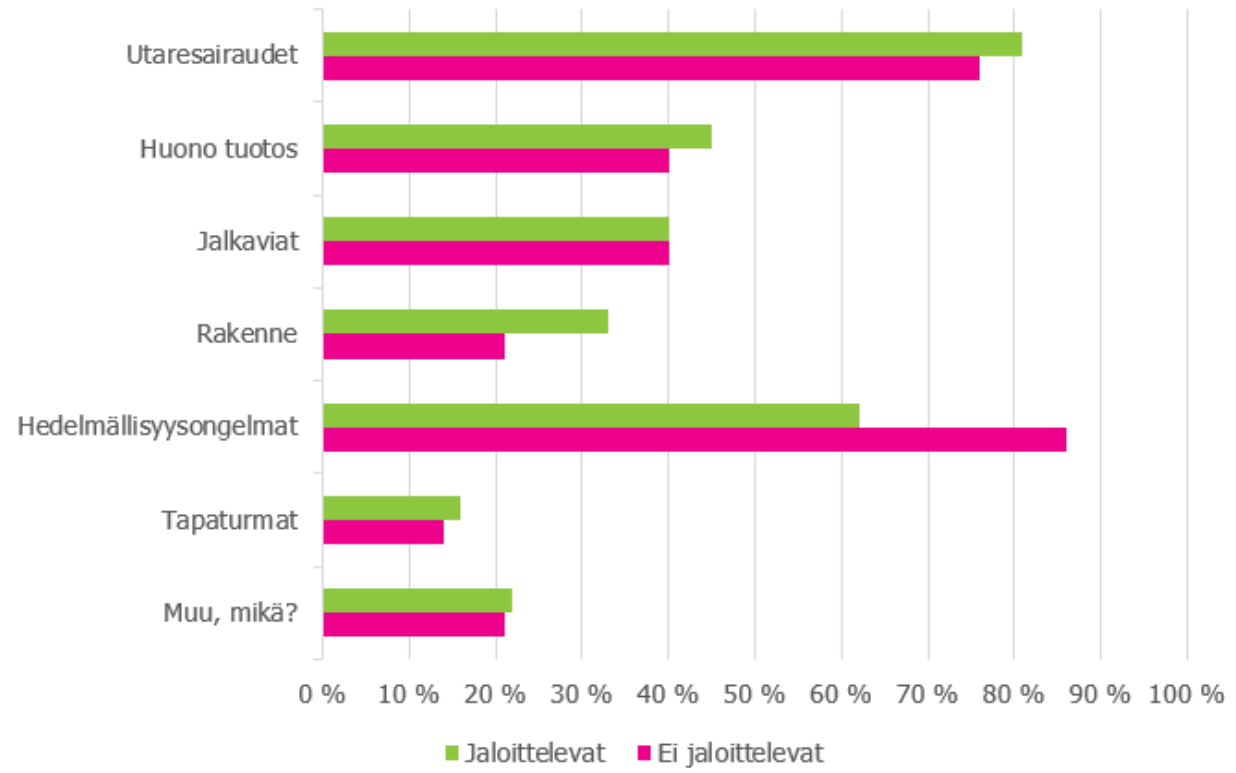

Kuva 2. Jaloitelleiden ja ei jaloitelleiden tilojen yleisimmät poiston syyt $(n=201)$

Suurin osa vastaajista ilmoitti tilansa eläinten keskipoikimakerraksi 2,1-2,5 tai 2,6-3. Suurimmalla osalla vastaajista keskipoikimakerta on siis lähestulkoon sama $(2,33)$ kuin keskimäärin Suomessa (ProAgria). Tuloksista on huomattavissa, että jaloittelevilla tiloilla on parempi keskipoikimakerta kuin ei-jaloittelevilla tiloilla. Jaloittelevista tiloista 42 \% ilmoittaa tilansa keskipoikimakerraksi 2,6-3, joka on selkeästi koko Suomen keskipoikimakertaa korkeampi. Yli 3,6 keskipoikimakertoihin päästiin vain harvalla tilalla (Kuva 3.) 


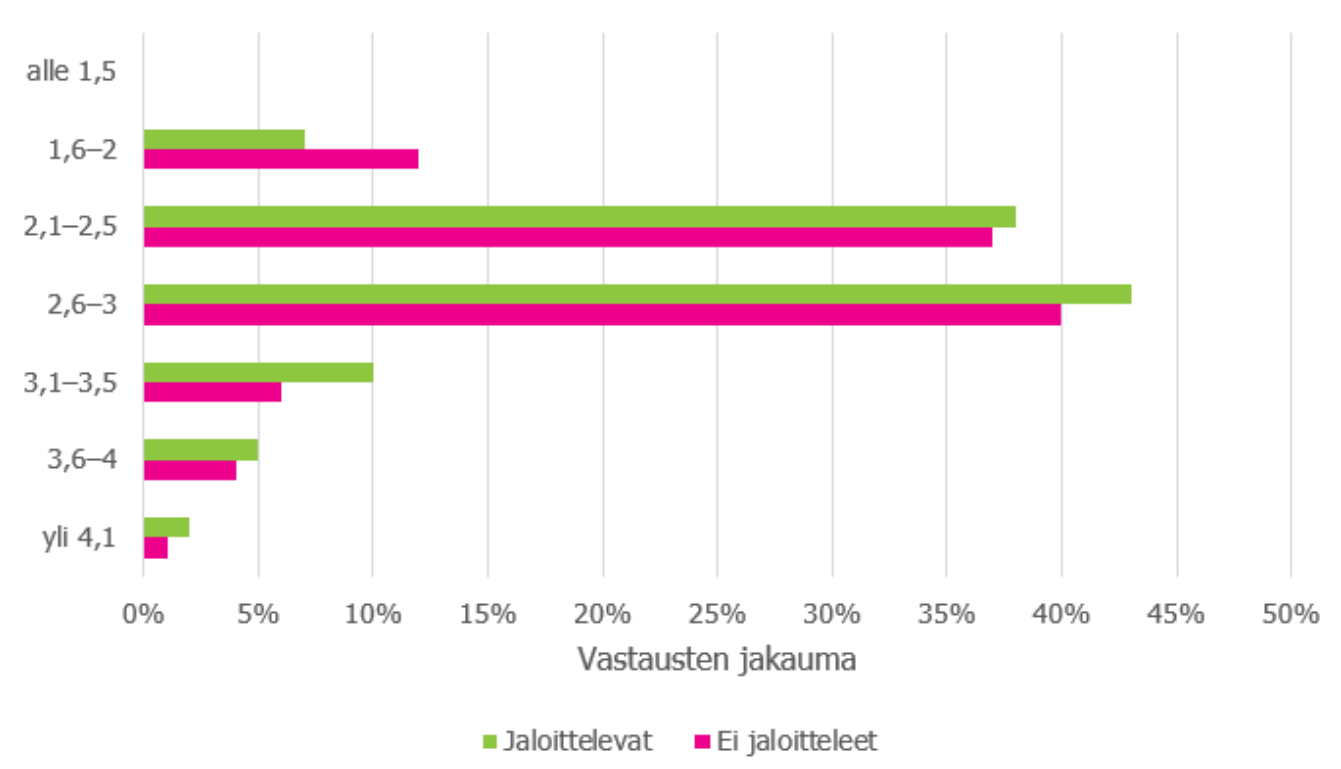

Kuva 3. Jaloitelleiden ja ei jaloitelleiden tilojen keskipoikimakerta (n = 201)

Ulkoiluttavilla tiloilla umpilehmät olivat sijoitettuna erilleen lypsävistä elämistä, joko erilliseen ryhmäkarsinaan, eri rakennukseen tai parsirivin päätyyn miltei kaikilla tiloilla. Jotkut tilat kertoivat, että umpilehmille oli järjestetty oma erillinen osastonsa. Verrattuna ei jaloitteleviin tiloihin tilanne umpilehmien sijoittelun kanssa oli huomattavasti parempi jaloitelleilla tiloilla (Kuva 4.) Tämä vaikuttaa varmasti umpilehmien hyvinvointiin, ruokintaan ja sitä kautta myös poikimisten sujumiseen tiloilla. Erillään lypsylehmistä sijaitsevat umpilehmät saavat todennäköisemmin omaa vähempienergistä rehua, joka vähentää umpikauden aikaista lihomista. Sitä kautta myös jotkin poikimisongelmat voivat vähentyä.

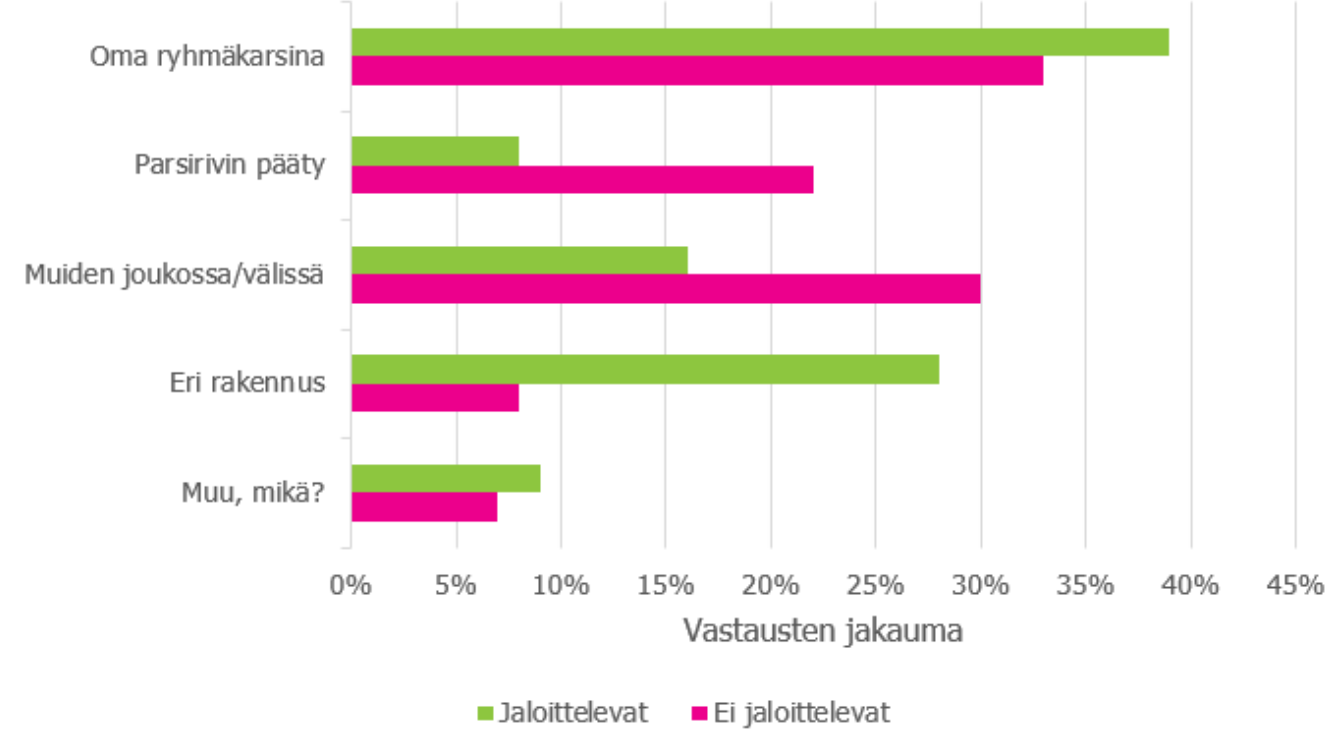

Kuva 4. Jaloitelleiden ja ei jaloitelleiden tilojen vertailu umpilehmien sijoittelun osalta navetassa $(\mathrm{n}=201)$

\section{Johtopäätökset}

Saadut tutkimustulokset tukevat sitä käsitystä, että jaloittelun avulla voitaisiin parantaa lypsylehmien hyvinvointia ja terveyttä. Aiemmin toteutetut tutkimukset ovat kuitenkin painottuneet enemmän parsilehmien eläinten terveyteen ja tuotokseen. Kyselytutkimuksessa huomattiin, että erityisesti parsinavetoiden eläinten hyvinvointi kohenee talviaikaisen jaloittelun avulla. Yrittäjät olivat havainneet muun muassa eläinten lihaskunnon kohentuneen huomattavasti. Tutkimuksen mukaan painoarvoa oli 
siirretty enemmän eläinten hyvinvointiin tuotoksen sijasta. Viitteitä saatiin siitä, että talviaikainen jaloittelu on hyväksi myös pihattonavetan eläimille. Toki jaloittelun hyödyt pienenevät pihattonavetoissa, koska eläimet pääsevät liikkumaan siellä vapaasti koko ajan.

Lumen ja talviaikaisen jaloittelun vaikutuksia sorkkaterveyteen ei ole tutkittu juuri ollenkaan.

Useissa eri lähteissä viitattiin ylimalkaisesti siihen, että lumi puhdistaa ja viilentää sorkkia. Tästä voi olla hyötyä joidenkin tartunnallisten sorkkasairauksien hoidossa. Kyselytutkimuksessa kävi ilmi, että jaloittelevat tilat kokevat eläinten sorkkaterveyden parantuneen. Samalla oli havaittu, että sorkat pysyvät paremmin puhtaina jaloittelun avulla. Tämä tieto tukee kirjallisuudesta saatua mielikuvaa, mutta konkreettisia tutkimuksia aiheeseen liittyen olisi syytä tehdä.

Kirjallisuuden mukaan liikunnan ja laadukkaan valon avulla karjan hedelmällisyys paranisi. Useissa tutkimuksissa on havaittu muun muassa se, että tarhassa eläimet voisivat toteuttaa kiimakäytöstään vapaammin ja täten näyttää kiimansa selkeämmin. Kyselyn perusteella voidaan sanoa, että yrittäjät olivat kokeneet jaloittelun selkeyttäneen kiimakiertoa, mutta läheskään kaikki vastaajat eivät olleet samaa mieltä. Eläinten kiimakierto ja kiimakäytös ovat hyvin monimutkaisia asioita ja riippuvat monesta eri tekijästä. Voi toki olla, että tarhassa eläimiä ei ole seurattu kovinkaan tarkkaan, jolloin kiimakäytöstä ei ole pystytty havainnoimaan. Siksi osa voi kokea, että talviaikainen jaloittelu ei ole juurikaan vaikuttanut hedelmällisyyteen. Tutkimustietojen mukaan jaloittelulla on kuitenkin havaittu olevan merkittäviä positiivisia vaikutuksia varsinkin parsinavetoiden eläinten kiimakiertoon ja kiimakäytökseen.

Jaloittelun suorista vaikutuksista poikimiseen tiedetään vielä vähän. Asiaa ei ole tutkittu kovinkaan paljon, mutta uskotaan, että jaloitelleiden eläinten poikimisten tulisi sujua helpommin kuin jaloittelemattomien. Syiksi perustellaan jaloittelun kautta parantunutta aineenvaihduntaa ja lihaskuntoa. Kyselyn perusteella tilalliset eivät ole kokeneet suoraa yhteyttä jaloittelun ja helpottuneiden poikimisten välillä. Vastaavasti eläinten oli koettu nousevan nopeammin poikimisen jälkeen ylös, mikä tukee sitä käsitystä, että jaloittelu pienentää poikimahalvausriskiä. Valitettavasti kaikkiin poikimavaikeuksiin ei voida vaikuttaa jaloittelun avulla, mikä selittää tilallisten näkemystä poikimisten sujuvuudesta ja siitä, miksi jaloittelu ei ole vaikuttanut niihin näkyvästi positiivisesti.

\section{Kirjallisuus}

Farm Animal Welfare Commitee. Covernment digital service. Viitattu 7.12. 2016.

https://www.gov.uk/government/groups/farmbanimalwelfarecommittee-fawc\#our-terms-of-reference

Maa- ja Metsätalousministeriö. Eläinsuojelulakia ollaan uudistamassa. Viitattu 15.4.2017.

http://mmm.fi/elainsuojelulaki.

ProAgria. Yli 150 lehmän tilat tuottivat 31 prosenttia tuotosseurannan maidosta. Viitattu 6.4.2017.

https://www.proagria.fi/ajankohtaista/yli-50-lehman-tilat-tuottivat-31-prosenttiatuotosseurannan-maidosta-489 